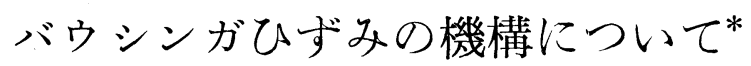

鵜 戸口英善** 岡 村 弘 之**

\title{
On a Mechanism of Bauschinger Strain
}

\author{
by \\ Teruyoshi Udoguchi and Hiroyuki OKamura
}

(Faculty of Engineering, University of Tokyo)

In this paper we have discussed on the relation between the stress and Bauschinger strain, which means the plastic strain caused by a reversed load in a transient-softening region.

The authors consider that Bauschinger strain can be caused by the random distribution of barriers against the movement of dislocations. The expression for the stress-strain relation in this region is established by the following assumptions: (1) The distribution of strength of barriers is normal, and (2) the effect of increase or decrease of the numher of dislocations on the strain is neglegible. According to this "random-barriers theory", the Bauschinger effect and some incidental phenomena can be explained considerably well. Moreover, the stress-strain relation derived by the theory agrees well with the experiments on low carbon steels. The authors conclude that Bauschinger strain is mainly caused by the random distribution of barriers especially in materials containing many obstacles such as internal stresses of various scales, segregates, inclusions, pile-up of dislocations and so on.

\section{1. 序言}

焼なましされた金属材料に荷重を加え塑性変形を与 えると加工硬化を起こす．このとさの応力ひずみ曲線 をFig. 1 の OA とし, のちの便宜のため, このとき の応力值が負になるように座標軸の方向を図のように 決める. 応力が $\tau_{0}\left(\tau_{0}<0\right)$, ひずみが $\gamma_{0}$ なるA 点の状 態から除荷してB点にもどし, 次にこの予荷重と同じ 向きの荷重を加えると, $\mathrm{BA}^{\prime} \mathrm{E}$ のような曲線に沿って 変形を生ずるが, もし B 点から上の予荷重と反対向き の荷重(すなわち正符号の荷重)を加えると， $\mathrm{BCD}$ な

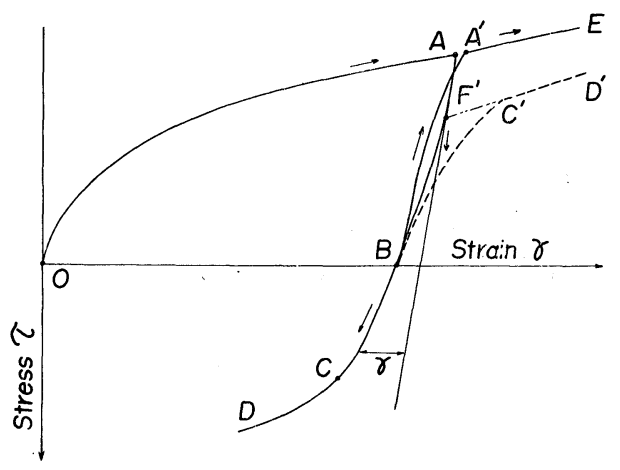

Fig. 1 Stress-strain diagram

\footnotetext{
* 原稿受付 昭和 36 年 5 月 20 日, 当協会第 10 期総会講演会(創立 10 ** 正員 東京大学工学部
}

る曲線を画いて変形を生ずる．B点を中心として曲線 $\mathrm{BCD}$ を $180^{\circ}$ 回転した曲線 $\mathrm{BC}^{\prime} \mathrm{D}^{\prime}$ と前の曲線 $\mathrm{BA}^{\prime} \mathrm{E}$ とを比較すると，一般に曲線 $\mathrm{BC}^{\prime} \mathrm{D}^{\prime}$ は曲線 $\mathrm{BA}^{\prime} \mathrm{E}$ よ り低く出て，材料が軟化していることを示す。これが バウシンガ効果である。この軟化は 2 部分からなるも のと見ることができる。すなわち図で $\mathrm{A}^{\prime} \mathrm{E}$ とほぼ平 行な $\mathrm{C}^{\prime} \mathrm{D}^{\prime}$ 部分は定常軟化の領域であり, それに至る までの $\mathrm{ABC}^{\prime}$ 部分は遷移軟化ともいうべき領域である. 金属が加工硬化を起こす領域 $\mathrm{OA}, \mathrm{A}^{\prime} \mathrm{E}$, および $\mathrm{CD}$ 部 については, 乐応力てとひずみ $\gamma_{W}$ との間に $\gamma_{W}=$ $\tau^{n}$ (ただし $n$ は 1 よりも大きい定数) なる $n$ 乗公式の 硬化特性を示すものが多いが, 上記の遷移軟化領域で は，応力てと塑性ひずみ $と$ と間にこの種の簡単な関 係は一般に成立しないので，ひずみを生ずる機構が各 領域で異なるものと考えられる。

また非常に興味深いのは, 各種の多結晶材料につい て加工硬化の応力ひずみ曲線が互いに異なるにもかか わらず，ほとんど同じ形の遷移軟化曲線が得られる点 である.降伏点の異なる弾塑性要素を組み合わせたモ デルによる Masing 流の理論はいろいろな書は物に広く 引用されているが，この理論によってはこの事実を説 明できず，また予ひずみがきわめて小さい場合以外は， この理論によって導かれた応力ひずみ曲線は実験結果 と一致しない.

単結晶も顕著な遷移軟化を示すことから, 遷移軟化 
の原因をもつと微視的なものに帰着させ，転位論によ る考察を行なった例も既にいくつかある。しかしそれ らはまだ単なる概念にとどまっていて，応力ひずみ図 を正確に導くに至っていない上うに見受けられる。

本報告は，遷移軟化領域における塑性ひずみ（これ をバウシンガひずみと称することにする)の生ずる原 因について一つの機構を提案したものである。そうし てこの考え方に基づき,かつそれに二,三の簡単な仮定 を加えて，遷移軟化領域における応力ひずみの関係式 を導きこれと炭素鋼についての実験を比較している.

\section{2. 抵抗力場の不規則分布}

単結晶においても著しい遷移軟化が観察されること は，バウシンガひずみの原因が転位の移動量以下のも のにも存することを示しているからこの現象の究明 には，転位論などによる微視的考察が必要と考える.

バウシンガひずみの原因は, もちろん単一の機構に 基づくものではなく, 既に提唱されている諸原因のほ かに多くの要因が複雑にからみあっていると考えなけ ればならないが，筆者らは遷移軟化の一原因として次 のような機構を考えた。すなわち遷移軟化が終るまで に転位がすべり面上を動く途中において，転位はその 原因がなんであれ，その移動に対する抵抗力の働く場 を通過しなければならない，この抵抗力場の山や䛦が 不規則な波形をなしていることをもって, バウシンガ ひずみを生ずる機構と考えるのである.

転位の動きに対する抵抗力場を形づくる原因はきわ めて多いが, 抵抗力が転位の位置の関数として定まっ ているポテンシャルカの場と, 位置だけでなく転位の 移動方向にも依存する非保存力の場とに大別すること ができると考える。

\section{（I） 保存的抵抗力場}

転位に働く力で位置の関数として定まるおもなもの は, 種ぶの尺度の内部応力で,これが転位に弾性的な 作用を及ぼす。この内部応力には，前記の Masing などがバゥシンガ効果の原因として想定していたと思 われる結晶粒の大きさ程度の波長をもつ内部応力 (Heyn stress) だけでなく，もっと微視的な内部応力, たとえばすべり帯付近の集中応力, 溶質原子や析出粒 子の回りの応力, 堆積転位や先行転位あるいは他のす ベり面の転位による内部応力などがある。これらの応 力の総和が転位に働く力となり，その動きに影響する が，これは一般にきわめて不規則な波形をなすものと 推察される.

\section{(II) 非保存的抵抗力場}

結晶中に含まれる折出粒子や不純物, あるいはすべ り面を貫く転位の林などは転位の動きに対して障害物 となり，その間隔にほぼ逆比例する抵抗力を生ずる。 そうしてこの間隔はもとより一定ではなく不規則であ
るから，抵抗力もランダムな分布をしている。この抵 抗力が ( I )の場合と違うのは, これらの障害物をどち らに向って通過するときにも抵抗を呈し, 転位の位置 のみならず，その運動方向によって抵抗が異なる。こ れを模形的に示したのが Fig. 2 (a)，(b)で，横軸に 転位の位置, 縦軸には転位に衝く抵抗力を示してある. 正方向への移動の場合を実線, 負方向への場合を点線 で示すと, 内部応力の場合は Fig 2 (a) の上うに両曲 線が一致し，(II) 項の抵抗力は Fig. 2 (b) のように 一致しない, またパイエルスカや, 転位がジョグをも っているための摩擦力も非保存的な力である.

結局, これら 2 種の抵抗力の和が実際の抵抗力場を 形成しているのであって, Fig. 2 (c) のようにきわめ て不規則な波形をなしていると考えるのが妥当であろ う.

非保存力の存在のために転位の動きはポテンシャル 力だけで論ずることができず，方向を考えなければな らないが，転位の移動方向が変わるときはその方向の 移動に対応する抵抗力場によってこれを論ずればよい. また遷移軟化の過程で転位の再配列が起こるので, 抵 抗力場は応力レベルに応じて变化する. 各応力レベル で転位の位置と応力をプロットした曲線を想定すると， 実はこれが実効的な抵抗力場になる。なぜならばある 応力レベルでの転位の位置というのは, そこでは抵抗 力がそのとき加えられている外力による応力とつりあ っていることを意味するので, この外力による応力が その位置の抵抗力の大きさを表わすことになるからで ある. そこでこのような実効的な抵抗力場を想定し, これによって転位の動きを論じなければならない，

抵抗力がいかなる原因によって生じているかをいま は問わないことにし，前述のようなランダムな抵抗力 場が存在すれば，これがバウシンガ効果あるいは遷移 軟化を生ずる機構となりうることを次に述べよう。

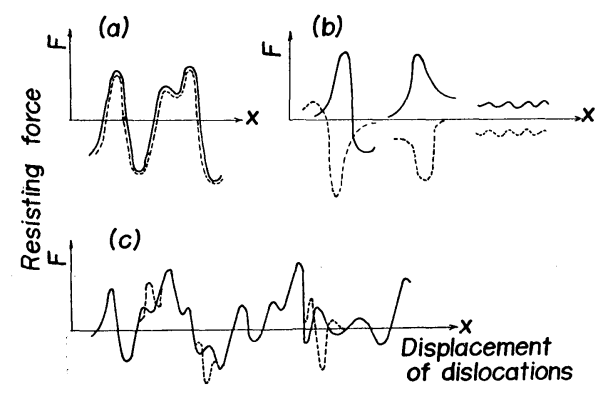

Fig. 2 The field of resisting force to the movement of dislocations
(a) conservative force
(b) non-conservative force
(c) actual resisting force
- for the to-motion
--- for the fro-motion 


\section{3. バウシンガひずみの一機構}

材料が Fig. 1 の $\mathrm{O}$ 点からA点まで変形を受ける間 には, 初めから存在していた障害のほかに転位の增殖 や堆積によって新たに多数の障害を生ずる.この多数 の障害は遷移軟化領域 $\mathrm{ABC}$ の間にすべて消隇してま た新しくできるわけではない，A点で存在していた不 純物粒子や転位は消隇するわけではないし, 転位の堆 積も比較的安定に存在している.したがってこの領域 でも不規則な抵抗力場は依然として存在しており, 变 化するとしても，それは局部的な小変化だけであると 考えたほうが妥当であろう。

また遷移軟化領域 $\mathrm{ABC}$ の間で新しいすべり線が観 察されていないことから,この領域では転位の增殖や 合体消隇は，ひずみの発生に二次的な影響しか及ぼさ ないものと考えられる．局部的に大きな内部応力のあ る部分で転位源が活性化されたとしても，この応力レ ベルでは乗り越せない障害の数が多いので, 転位の進 む距離が短く，また，転位源に及ぼす逆応力も大きい のでひずみに対する寄与が少ないことも考えられる。 そこで以下ではまず, 転位が不規則な抵抗力場を進 むことによっていかなる現象が生ずるかを調べてみよ う.

Fig. 3 は抵抗力の大きさを応力の単位で表わしてあ る。すなわち転位の単位長さに働く抵抗力をバーガー スベクトルの大きさ $b$ で割ったもので表わし，これを $\tau_{F}$ とかく．外力による応力がてなるとさに転位が安 定なつりあい状態にあるためには, 両者の值が等しい ことのほかに, 転位がつりあい位置から微小量動くと, それを元の位置に引きもどす力が働かなければならな いから, 安定平衡の条件は次のようになる。

$$
\tau_{F}=\tau, \quad d \tau_{F} / d x>0
$$

したがって, 応力が $\tau_{0}$ のときは Fig. 3 の $P_{1}^{*}$ 点, $P_{3}^{*}$ 点などは不安定平衡点であって, このような位置には 転位がない. $P_{1}$ 点, $P_{3}$ 点などの安定平衡点に対応す る $x$ 座標の所だけに転位が存在する。この図では簡単 のため，Fig. 2 (a) のような正負両方向移動に同じ



Fig. 3 Movement of dislocations
力を及ぼす抵抗力場をかいてあるが，変形方向によっ て抵抗が違う場合でも変形方向に対応する抵抗力を考 えれば，以下の扱いは同じことになる．Fig. 1 のA 点に刘応する状態では，転位はこのような抵抗力場の 大さな山のてまえにある。これから荷重を除くと応力 $\tau$ の值が代数的な意味で増加して，荷重が 0 になるま でには $P_{1}$ の位置にある転位は $P_{2}$ に, $P_{3}$ 点にある転 位は $P_{4}$ で山を越して $P_{4}^{\prime}$ にぶつかり $P_{6}$ に至る。ここ で負の応力(予荷重と同方向の荷重による応力)を加え ると $P_{2} \rightarrow P_{1}, P_{6} \rightarrow P_{5} \rightarrow P_{5}^{\prime} \rightarrow P_{3}$ の変化をしてわずかに ループを画き元の状態にもどる.これが Fig. 1 の $\mathrm{BA}^{\prime}$ 部分に対応する. 逆に $\tau=0$ の状態から応力を正の方 向(予荷重と逆方向)に增すと， $P_{7}$ のような山の数も 多くなり，また跳び越す量 $\overline{P_{7} P_{7}^{\prime}}$ が大きくなる。した がって応力レベルが高まるにつれて転位の移動量が急 激に增加する。この過程が Fig. 1 の曲線 BC に相当 し，ここで転位の移動量が大きくなることが遷移軟化 の原因である，そうしてこのとき現われるひずみがバ ウシンガひずみであると考える. $P_{6} \rightarrow P_{7} \rightarrow P_{7}^{\prime} \rightarrow P_{8}$ と 動いた転位は応力の向きを変えれば $P_{8} \rightarrow P_{9} \rightarrow P_{10} \rightarrow$ $P_{10}{ }^{\prime}$ のように動き，応力ひずみ図は大きなループを描 く.

以上がバウシンガひずみの生ずる機構の大略である が, バゥシンガ効果に関する内部応力説, 障害物説, 先行転位による逆応力と摩擦力を原因とする説などは, いずれも上述の機構の特別の場合と考えることができ る.

\section{4. バウシンガひずみの定式化}

まず Fig. 3 のような一次元的なモデルによって遷 移軟化領域の応力ひずみ曲線を求め上う。この領域で は転位の增殖はひずみに大きな笴与をしないと考元， 変形に関与する転位の数をほぼ一定とみなす。そうう て不規則分布をしている抵抗力の場を転位が通過して いく場合に生ずるひずみを計算してみる。

塑性ひずみとは転位が抵抗力の山を越えて, 次の大 きな山の前まで動くために生ずる部分 $\gamma_{1}$ と，山のす そ野を上下するために生ずる部分 $\gamma_{2}$ からなる。

变形に関与する転位の数を単位面積あたり $N$ ，その バーガースベクトルの大きさを $b$ とする。あるひずみ 速度において，応力てでは越えることのできない障害 すなわち抵抗力場の山が，すべり方向単位長さあたり $H(\tau)$ 個だけ存在するとする。この中には熱摇動に助 けられて障害を越すことも考えて実效的な数を考えて おく，応力レベルがてから $\tau+\delta \tau$ までわずかに増加 したとき，この間に乗り越えうるようになる障害の数 は $-(d H(\tau) / d \tau) \cdot \delta \tau$ である。したがってこれらの障 害の前に堆積していた転位は山を越して動くようにな る.この転位の数 $\delta N$ と全転位数 $N$ との比は, コット 
レル・ロッキングのようなくぎづけ作用を考えないで よい場合は上記の障害の数と $H(\tau)$ との比と考えられ るから

$$
\frac{\delta N}{N}=\frac{-\left(\frac{d H(\tau)}{d \tau}\right) \cdot \delta \tau}{H(\tau)}
$$

したがって

$$
\delta N=-\frac{N}{H}\left(\frac{d H}{d \tau}\right) \cdot \delta \tau
$$

なる数の転位が障害物の平均間隔 $1 / H(\tau)$ だけ進んで 次の大きな障害の前に止る。したがってこのために生 ずるひずみ $\gamma_{1}$ の增分 $\delta \gamma_{1}$ は

$$
\delta \gamma_{1}=b \cdot \frac{1}{H} \cdot \delta N=-\frac{b N}{H^{2}} \cdot\left(\frac{d H}{d \tau}\right) \cdot \delta \tau
$$

ゆえにひずみの增加率は，

$$
\frac{d \gamma_{1}}{d \tau}=-\frac{b N}{H^{2}} \cdot \frac{d H}{d \tau}
$$

である、障害のすそ野の平均こう配を

$\alpha=\left(d \tau_{F} / d x\right)_{\text {mean }}$ とおくと,すそ野をのぼるためのひ ずみの $\gamma_{2}$ 增分は

すなわち，

$$
\delta \gamma_{2}=\frac{N b}{\alpha} \delta \tau
$$

$$
\frac{d \gamma_{2}}{d \tau}=\frac{N b}{\alpha}
$$

となる。したがって応力が $\tau_{0}$ からてまで増加する間 に生ずる塑性ひずみ $\gamma は ，$ 前述のように $N$ を一定と考 えて(1)，(2)両式の和を積分することにより次のよ うに得られる。

$$
\gamma=\gamma_{1}+\gamma_{2}=N b\left\{\frac{1}{H(\tau)}-\frac{1}{H\left(\tau_{0}\right)}\right\}+\frac{N b}{\alpha}\left(\tau-\tau_{0}\right)
$$

(3)式の第 2 項は見掛上弾性変形が増したと同じ効 果を現わすが， $\gamma_{1} \gg \gamma_{2}$ と考えてこれを省略することに する。ここで障害物の密度分布を簡単に平均値 $\tau=$ $\tau_{m}$, 標準偏差 $\sigma$ の正規分布すなわち，

$$
-\frac{d H}{d \tau}=-\frac{2}{d_{m}} \cdot \frac{1}{\sqrt{2 \pi} \cdot \sigma} \exp \cdot\left\{-\frac{\left(\tau-\tau_{m}\right)^{2}}{2 \sigma^{2}}\right\}
$$

と仮定する．ただし， $d_{m}$ は $\tau=\tau_{m}$ における障害の平 均間隔である。したがって，

$$
r(\tau)=\frac{N b d_{m}}{2}\left(\frac{1}{\int_{\tau}^{\infty} \frac{1}{\sqrt{2 \pi} \cdot \sigma} \exp \cdot\left\{-\frac{\left(\tau-\tau_{m}\right)^{2}}{2 \sigma^{2}}\right\} d \tau}-1\right)
$$

とおくと，塑性ひずみは

$$
r(\tau)=\stackrel{*}{r}(\tau)-r^{*}\left(\tau_{0}\right)
$$

と書ける。

Fig. 4 はてと $\gamma^{*}(\tau)$ との関係を示したもので, 標準 偏差 $\sigma$ が增減するとそれに比例して曲線は上下に伸縮 する.この $r^{*}(\tau)$ から值の小さな定数 $r\left(\tau_{0}\right)$ を引けば応 力ひずみ曲線が得られる。

転位は直線状ではなく，実際には屈曲しているし， また 1 本の転位のうちの小さな部分が障害を乗り越え
ていく、このような二次元的な転位の進行に対するモ デルに拡張するにあたっては，いろいろな考え方がで きる，たとえば単位体積中に存在する障害の分布を正 規分布と仮定し, 転位の一部が平均間隔 $d$ なる障害を 一つ越えるとき，長さが $d$ 程度の部分が $d^{2}$ 程度の面 積を掃くものと考えると，前と同様な定式化ができる. すなわち( 5 )式に対応して，

$\stackrel{*}{r}(\tau)=k \frac{N b d_{m}}{2}\left\{\frac{1}{\left\{\int_{\tau}^{\infty} \frac{1}{\sqrt{2 \pi} \cdot \sigma} \exp \cdot\left(-\frac{\left(\tau-\tau_{m}\right)^{2}}{2 \sigma^{2}}\right) d \tau\right\}^{n}}-1\right\}$

が得られる、ただし $k$ は定数, $n$ はこの場合 $2 / 3$ とな る.（5)式の場合は $k=1, n=1$ だったわけである. たとえば障害物の分布を単位体積中で正規分布をして いると考えずに，すべり面上で正規分布をしていると すれば $n=1 / 2, k=2 \sqrt{2}$ となる．その他変形の仕方 などの考え方によってnの值は若干異なる。このnの 值によって Fig. 4 の曲線の形は少し变化する．しか しnとして 1 から $1 / 2$ の間のどの值をとるにしても， $\tau=\tau_{m}$ 付近での応力ひずみ曲線のこう配が等しくな るようにのの值をそれぞれの場合に応じて適当に選べ ば，応力ひずみ曲線の形はほとんど变わらない。

\section{5. 実験結果との対比}

$0 \cdot 1 \%$ 炭素鋼の薄肉称じり試験片（外径 $21 \mathrm{~mm}$, 内径 $19 \mathrm{~mm}$ ) を乾燥純水素気流中で $915^{\circ} \mathrm{C}$ において 1 時間焼なまし，炉中冷却する。この試験片をねじっ た場合の応力とバウシンガひずみの関係を片対数方眼 紙上にプロットしたのが Fig. 5 の〔I Iおよび〔II]の 実験点である。この応力ひずみ曲線は図からわかるよ うに簡単な形にならない. 両対数方眼紙上にプロット しても，この事情は変わらない。

図中の実線は ( 5 )式および $(6)$ 式から得られた計算

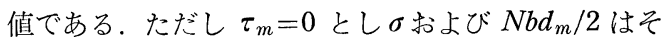

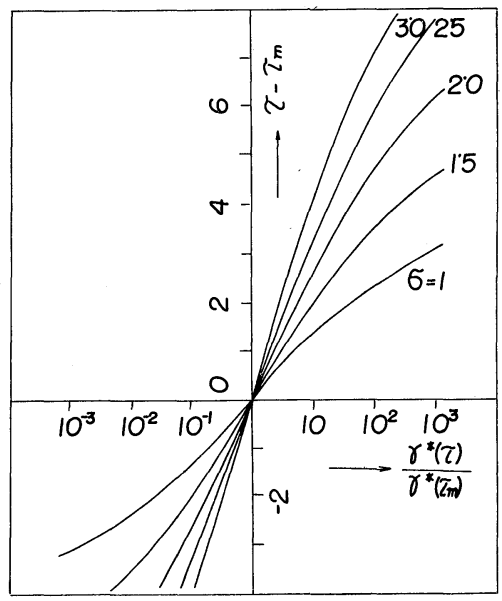

Fig. $4 \gamma^{*}(\tau) \sim \tau$ relation in Eq. (5) 
れぞれ て $=0$ におけるこう配およびひずみが等しくな るように適当に決めてある.

曲線〔 I ]は予荷重による変形において応力が下降伏 点に達しているが，ひずみ塗料により検出されるひず 夕線が試験片全長に広がらないうちに除荷し, 逆方向 の負荷を行なったものである。除荷開始点の応力は下 降伏点 $\tau_{0}=-9 \cdot 2 \mathrm{~kg} / \mathrm{mm}^{2}$ であるが， $\tau$ が $\left|\tau_{0}\right|$ に達す るまで降伏部分の拡大は見られず，下降伏点に達して 初めて桩大が見られる。これを Fig. 1 のような応力 ひずみ図と対応してみると, 遷移軟化領域は $\tau /\left|\tau_{0}\right|=$ -1から $\tau /\left|\tau_{0}\right|=+1$ までの全域にわたっており，こ

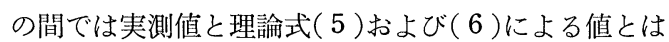
かなり良く一致している。

曲線〔エ〕は，同じ試験片をさらにねじり，荷重の方 向を数回途中で変えつつ, $\tau_{0}=-20 \cdot 7 \mathrm{~kg} / \mathrm{mm}^{2}$ すな わち下降伏点の 2 倍以上硬化した状態にもちきたした 後の応力とバウシンガひずみの関係であって，これに 至るまでの塑性ひずみの絶対值の和は約 $80 \%$ にもな っている. 図に 2 点鎖線で書さ入れてある曲線は， Fig. 1 において $F^{\prime} C^{\prime} D^{\prime}$ で表わされる定常軟化領域の

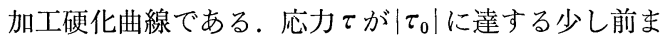
では, 応力・ひずみの測定点は遷移軟化の理論曲線に かなりよくのり， $\left|\tau_{0}\right|$ に近くなると加工硬化曲線上一 移行する。このことから遷移軟化領域では前述の機構 によってひずみを生じ，加工硬化域(定常軟化領域)に はいると転位の増殖がひずみの発生に重要な役割を演 ずるもののように推察される。

Fig. 5 では, $\tau /\left|\tau_{0}\right|$ を緃軸にとってあるが，こう すると $[\mathrm{I}]$ と $\mathrm{II}]$ の遷移軟化部分は子ひずみ $\gamma_{0}$ に著 しい差があるにもかかわらずほぼ平行になる。このこ とは標準偏差 $\sigma$ がほぼ $\left|\tau_{0}\right|$ に比例することを意味す る．また図での平行移動のひずみ量は等分目盛で考え

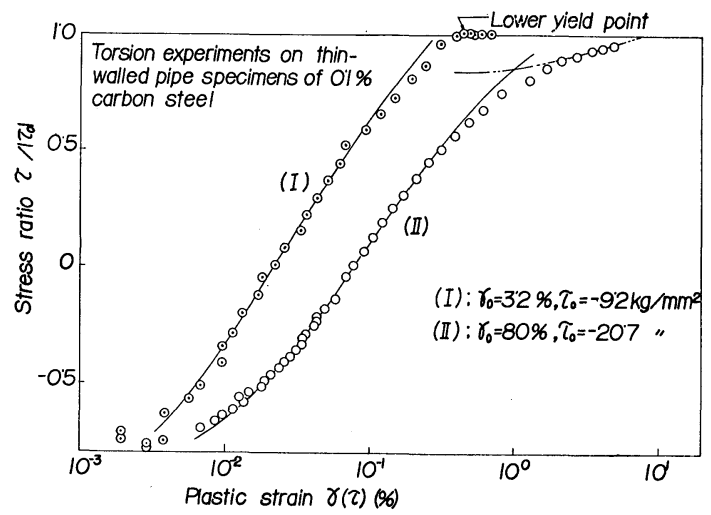

Fig. 5 Stress-strain curves under the reversed load

the theoretical curves according to the Eqs. (5) and (6), where $\tau_{\mathrm{m}}=0$ - ..- the work-hardening curve
るとほぼ $\left|\tau_{0}\right|$ に比例するようである。これらのことか ら加工硬化の途中において加工硬化応力 $\left|\tau_{0}\right|$ が $N d_{m}$ に比例すること，また種々の加工硬化状態 $\tau_{0}$ に対応 するバウシンガひずみは大略 $\gamma(\tau) \propto\left|\tau_{0}\right| \cdot f\left(\tau /\left|\tau_{0}\right|\right)$ で 表わされるが, この関数 $f$ の形を与えるのが, 障害の 正規分布であると考えられる.

Fig. 6 は, 熊倉氏による実験結果で, 焼なまし状態 の各種炭素鋼にほぼ同程度の予ひずみ $\gamma_{0}$ を与えた後 のバウシンガひずみと応力の関係である．ただし比較 のため各曲線が同一点を通るようバウシンガひずみ $\gamma(\tau)$ を $\tau=0$ における塑性ひずみ $\gamma(0)$ (Fig. 1 のB点) で割ったものを横軸にとってある。図中の曲線は ( 5 ) (6)両式による理論曲線で, 適当な $\sigma$ の值を選んで書 いてある.これらの曲線群は Fig. 4 と同じ傾向を示 しており，予ひずみ，含有炭素量などによる障害の分 布の違いをよく表わしていると考えられる.

\section{6. あ と が き}

本報告ではバウシンガひずみを生ずる一つの機構と して，転位の移動に対する抵抗力が不規則な分布をし ていて，この中を転位が通過していくというモデルを 提案した. 次にこのモデルに基づき二, 三の簡単な仮 定を加えてバウシンガひずみと応力との関係式を導い た．加工硬化領域における応力とひずみの関係も確立 されていない現状において，上述のような大まかな推 論により得たバウシンガひずみと応力との関係式が完 全なものであるとはもとより考えていない。また上述 のモデルの適否を確かめるには，なお多数の理論的，

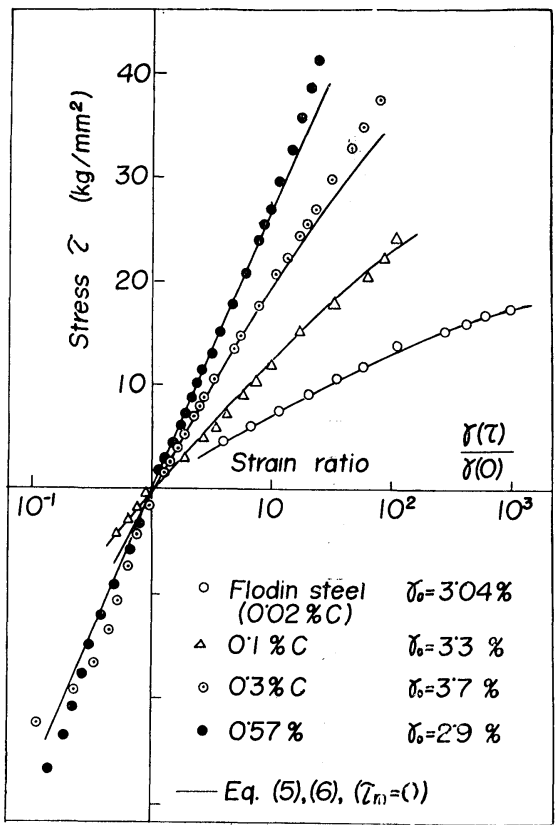

Fig. 6 Stress-strain curves for carbon steels (after S. Kumakura) 
笑験的研究を要するが，ともかくも低炭素鋼の実験と はかなり良く一致する結果を得たので，ここに報告し た次第である。

たとえば単結晶のように，材料中に含まれる障害物 の数が少ない場合に現われるバウシンガひずみは，本 報告に提案したような障害乗り越えの機構で解釈する より, 内部逆応力を主原因と考えるほうがより適当で あるかもしれない。しかし一般の各種の障害物を多く 含んだり，加工硬化により多数の転位を含むような実 用材料については，ここに述べ障害乗り越えの機構 に基づくひずみがバウシンガひずみの大きな部分を占 め，その応力ひずみの関係は本報告に導いた式に合う であろうと考える。

遷移軟化領域における応力とひずみの関係あるいは バウシンガひずみの生ずる機構は, 材料の疲労および 内部摩擦とも密接な関係をもち, これらの現象やさら
に加工硬化現象の究明に有力な手がかりを与えうる興 味ある問題と考える.

本研究は, 昭和 35 年度文部省科学研究費, および 昭和 35 年度河上記念財団研究助成金によるものであ る。また愁篤な御教示と貴重な資料を提供していただ いた, 山形大学熊倉重典氏, 試験機や試験片の一部の 製作をお願いした日立製作所宮本博氏，実験に協力し ていただいた東京大学 35 年度卒業実験の志賀勝利, 高畑富久, 竹村敬生の諸君, その他本研究について御 援助, 御指導をいただいた多くの方々に深く感謝いた します。

\section{参考文 献}

1) R.L. Woolley, Phil. Mag,. 353, p. 597 (1953)

2) G. Masing, Z. Tech, Phys., 3, 167 (1922)

3) S.N. Buckley and K.M. Entwistle, Acta Met., 4, p. 352 (July 1956)

4）熊倉重典, 未発表
(993頁より)

Material Res. \& Stand., Vol. 1, No. 2, (Feb. 1961)

$-423^{\circ} \mathrm{F}$ 下の引張試験における寒片およびその付属 品 (J.F. Watson and J.L. Christian, 87/90) 液体 窒素を寒剤とする低温度での引張試験装置について述 へ，付属品として液位計，熱電対，ヒーターおよび低 温度で用いる伸び計などについて触れたもの。

○標準外のシャルピー試験片による試験結果と標準 シャルピー試験片による試験結果との関係 (Charles H. Curll, 91/94) 薄厚および小径断面の材料から試 験片を造らねばならない場合の標準外 $\mathrm{V}$ ノッチ・シャ ルピー試験片による衝撃值と, 標準試験片によるそれ との間の関係を調へるため二, 三の合金鋼について実 験を行なった結果 $-40^{\circ} \mathrm{C}$ の温度において両者の間に 直線関係のなりたつことを指摘.

$\bigcirc 4 \sim 300^{\circ} \mathrm{K}$ の温度に対する引張試験用寒剤 (R.M. McClintok and K.A. Warren, 95/98), 4 300 ${ }^{\circ} \mathrm{K} の$ 温度下の引張試験を行なう場合の寒剤の選択およびそ の成績について述べたもので, これらの温度に対して は液体空素が簡便, 安全性の上ですぐれていることを 指摘.
○Floor Covering の厚み測定に対するマイクロメ ーターおよび微測光学計の評価 (E. Horowitz, J. Mandel, R.J. Capott and T.H. Boone, 99/103)

Floor Covering の厚み測定に対するダイヤル・ゲ ージ・マイクロメーターおよび微測光学計における測 定方法についての共同研究結果を述べたもの.

$\bigcirc 304$ 型不銹鋼の $1350^{\circ} \mathrm{F}$ におけるクリープ破断試 験 (W.D. Jenkins, W.A. Willard and W.J. Youden, 104/108), 304 型不銹鋼の単一熱処理から得られ た試験片について温度 $1350^{\circ} \mathrm{F}$, 引張応力 $13500 \mathrm{psi}$ でクリープ破断試験を行ない，その破断寿命は平均寿 命 $100 \mathrm{~h}$, 標準偏差 $20 \mathrm{~h}$ であることを示し, また結果 のばらつきに対しては材料組成のばらつきが試験装置 によるばらつきよりも大きな因子であることを指摘.

○銅合金に対する簡便な応力腐食試験 (D.H.

Tompson, 108/111) 湿度のあるアンモニヤふんい気 中での銅合金の応力腐食割れに対する強度を決める簡 便な試験方法について論じたもの.

○燃料中の未溶解水分の決定に対する新しい方法 (L. Gardner and G. Topol, 112/115) ジェット燃料 中の微量つ未溶解水分の決定法を論じたもの.

(大南正嘆) (1005 頁へ) 